\title{
Beside My Sister, Facing the Enemy: Legal Theory Out of Coalition*
}

\author{
Mari J. Matsuda**
}

\section{INTRODUCTION}

The Third Annual Conference on Women of Color and the Law, held in October 1990 at Stanford Law School, was coalition: individuals from divergent social backgrounds and positions coming together to work toward a common goal. From all corners of the country hundreds of women and dozens of men came. For the most part, they were law students, but their differences in size, shape, color, hair, speech and attire were so wondrously dramatic that no one wandering into the large auditorium where they gathered would have thought, "Ah, a meeting of law students." No, it looked more like a convocation of proud tribes. Sitting in the sun on perfect Stanford lawns, conference participants laughed and talked politics as though they did this every weekend. White with Black, native with immigrant, lesbian with straight, teacher with student, women with men-as though the joy of communing across differences was their birthright.

Conference organizers and volunteers-themselves as diverse as their guests-buzzed about busily in their official T-shirts, arranging rides, watching the clock, shepherding speakers, smoothing over misunderstandings. Watching these students work so easily with each other almost made me forget that a year of struggle, anger, tears, fears, and consciousness-raising had brought them to their day in the sun. Each one had asked at some point during that long year preceding the conference, "Is it worth it?"

"Is it worth it?" is the question every person who works in coalition confronts. ${ }^{1}$ This essay introduces the work of three writers who themselves

* This title was inspired by a line from Pablo Neruda, Los Versos del Capitań (The Captain's Verses) (New Directions ed. 1972):

y en medio de la vida estare' siempre, junto al amigo, frente al enemigo

(and in the midst of life I shall be always beside the friend, facing the enemy)

This essay was written at the request of the Conference organizers, who sought an introduction to the Trask, Inuzuka, and Parker presentations.

** (C) 1993 by Mari J. Matsuda. Professor of Law, University of California at Los Angeles School of Law. The author thanks the organizers of the Stanford Conference on Women of Color and the Law, and the following colleagues who commented on drafts of this essay: Kimberlé Crenshaw, Clarel Cyriaque, Charles R. Lawrence III, Lisa Lim, and Stephanie Wildman.

1. Bernice Johnson Reagon, in her well-known essay on coalition, said, "You don't go into coalition because you just like it." Bernice Johnson Reagon, Coalition Politics: Turning the Century, in HoMe GiRLS: A BLACK FeMinist ANThology 354 (Barbara Smith ed. 1983). She goes on to state: "And you shouldn't look for comfort. Some people will come to a coalition and they rate the 
have asked and answered that question many times over. By their example, they show that the gains from coalition outweigh the pains. Implicit in their work is a knowledge of self that allows them to act in coalition, all the while knowing that the time may come when they must break coalition in order to preserve their own integrity and purpose.

This essay introduces the works of three writers: Haunani-Kay Trask, June Inuzuka, and Sharon Parker. It then considers the relationship between the process and the substance of coalition, suggesting that the instrumental use of coalition-building to achieve certain political goals is merely the beginning of the worth of this method. The deeper worth of coalition is the way in which it constructs us as ethical beings and knowers of our world. This essay concludes with tentative suggestions of the type of substantive theory that may emerge from work in coalition. ${ }^{2}$

\section{THREE WOMEN WORKING}

\section{A. Daughter of Pi'ilani ${ }^{3}$}

Haunani-Kay Trask is a paradox to those unfamiliar with the world from which she comes. She writes of working in coalition with environmentalists who, in her community of Hawai'i, are often white in-migrants. ${ }^{4}$ Expressing bitterness and frustration, Trask recounts the dispossession of Native Hawaiian people-their landlessness, poverty, unemployment, imprisonment, rates of disease, and illiteracy. Trask speaks of the haole (Caucasian) colonizers who removed the Hawaiian government by force, leaving wounds in the native population that have never healed. ${ }^{5}$ Expressing outrage at the haole-backed takeover of Hawai'i has earned Trask the reputation of "haole-hater." She speaks out in the press. ${ }^{6}$ She writes. She debates.

success of the coalition on whether or not they feel good when they get there. They're not looking for a coalition: they're looking for a home!" Id. at 359.

As Professor Kimberlé Crenshaw pointed out to me upon reading this essay: "Comfort means perfect peace or perfect oppression."

2. For general discussions of anti-subordination principles, see CHARLES LAWRENCE, MARI J. Matsuda, Richard Delgado \& Kimberle Crenshaw, Words That Wound: Critical RACe Theory, Assaultive SPEech, and the First AMENDMENT (forthcoming); Mari J. Matsuda, Voices of America: Accent, Antidiscrimination Law, and a Jurisprudence for the Last Reconstruction, 100 YALE L.J. 1329 (1991); Ruth Colker, Anti-Subordination Above All: Sex, Race and, Equal Protection, 61 N.Y.U. L. REv. 1003 (1986); Lucie E. White, Subordination, Rhetorical Survival Skills, and Sunday Shoes: Notes on the Hearing of Mrs. G., 38 BuFf. L. REv. 1 (1990).

3. Professor Haunani-Kay Trask was introduced at the Conference as the genealogical descendant of the Pi'ilani line of Maui, the non-self-governing Native Hawaiians. She is the author of Eros and Power: The Promise of Feminist Theory.

4. See Haunani Trask, Coalition-Building Between Natives and Non-Natives, 43 STAN. L. REv. 1197 (1993).

5. See Haunani-Kay Trask, Politics in the Pacific Islands: Imperialism and Native Self-Determination, 16 AMERASIA 1 (1990). The article discusses the effects of imperialism on Hawaiian culture. Trask suggests that the power of Native Hawaiian self-definition was impeded by repression of the Hawaiian language. The ability to conceptualize in Native terms was hampered when all cultural referents became those of non-natives. Id. at 3 . In addition to the psychological and political colonization of Native Hawaiians, Trask notes the physical appropriation of Native lands resulting in the denial of control over the land and its peoples. Id. at 9.

6. See Racial Dispute Erupts at UH-Manoa, Honolulu Advertiser, Oct. 26, 1980, at A-3. 
Trask is constantly engaged in dialogue with the haole. She works with whites in coalition on a variety of issues, from nuclear testing in the Pacific, to South African divestment, to degradation of the environment through geothermal development.

I have heard people say of Professor Trask, "She would be much more effective if she weren't so angry," as though they expect a Native Hawaiian feminist to work in coalition without anger. There is a politics of anger: who is allowed to get angry, whose anger goes unseen, and who seems angry when they are not. ${ }^{7}$

Once, when I intended to compliment an African-American woman on a powerful speech she had made, I said: "I admire your ability to express anger." She looked at me coolly and replied, "I was not angry. If I were angry I would not be speaking here." Another African-American friend of mine jumped into the conversation. "I'm disappointed in you," she said. "This is what always happens to us when a Black woman speaks her mind. Someone calls us angry."

I remember this exchange because it was an uncomfortable one for me, and because it was a moment of learning. Talking across differences, my colleague told me that if she were hatefully angry, beyond hope of coalition, she would not talk. In this light, Professor Trask's strong words are acts of engagement, not estrangement.

Would Professor Trask be more effective if she were less angry? There is a cost to speaking without anger of the deaths and dislocation that native Hawaiians suffered in post-contact Hawai'i. ${ }^{8}$ On the simple, communicative level, failure to express the pain created by this legacy obscures the depth of one's feeling and discounts the subordination experienced by one's community. More significantly, the use of polite, rational tones when one is feeling violation is a betrayal of the self.

Professor Trask's many white and Asian colleagues who choose to remain in the room when she speaks in tones of outrage about the destruction of Hawaiian lives, land, and culture inevitably find their understanding greatly enriched. The discomfort brings with it an opportunity for learning. As a third-generation Japanese-American, I have felt the discomfort and benefitted from the learning when Professor Trask criticizes the role of immigrants in displacing Native Hawaiians. The choice is mine to remain in the conversation, discussing (sometimes with acrimony) the role of colonialism in bringing my peasant ancestors eastward from Asia to work on land that once belonged to indigenous peoples of Hawai'i and North America.

I could shelter myself from conflict by leaving the conversation, but I have come to believe that the comfort we feel when we avoid hard conversations is a dangerous comfort, one that seduces us into ignorance about the

7. See Trina Grillo, The Mediation Alternative: Process Dangers for Women, 100 YALE L.J. $1545,1576-81$ (1991).

8. For a historical assessment of the mass deaths and social dislocation in the Native Hawaiian population as a result of western contact, see David E. STANNARD, BEFore THE HORROR: THE POPULATION OF HAWAI'I ON THE EVE OF WESTERN CONTACT (1989). 
experiences of others and about the full meaning of our own lives. ${ }^{9}$

\section{B. Women of Color and Public Policy}

In her article for this symposium, June Inuzuka writes of coalition as strategy. ${ }^{10}$ Her concept of coalition is grounded in the world of practical politics and in the recognition that women of color are a numerical minority in the arena of policy formation. In order to meet the immediate and material need for access to government largess, Inuzuka and others like her have worked within organizations dominated by white, middle-class women. Inuzuka's case study of the Women's Business Ownership Act ${ }^{11}$ provides a useful descriptive vehicle for exploring the costs and benefits of coalition. Women of color ${ }^{12}$ who worked for the Act's passage chose to integrate with largely white ${ }^{13}$ feminist organizations. This choice, as Inuzuka's essay reveals, allowed these women of color to influence public policy.

There is a realpolitik awareness in the way Inuzuka approaches her work. She has chosen to de-emphasize the separate and sometimes conflicting categorizations of "white feminist" and "women of color" in coalitionbuilding. Given her mission-to stop legislative developments that could disadvantage women of color as a group-this choice makes sense. Demanding meaningful representation for women of color in the political process requires the dual coalitions that Inuzuka writes about: the coalition of women of color, and the coalition of women of color united with white feminists.

Inuzuka chooses not to problematize the categories "white feminist" and "women of color." This non-deconstructionist approach contrasts with the work of theorists who challenge our thinking about the make-up of the feminist coalition. ${ }^{14}$ Inuzuka is an example of an activist who recognizes differ-

9. For a discussion of the costs of silence, see King-Kok Cheung, Don't Tell: Imposed Silence in The Color Purple and The Woman Warrior, 103 Publications Mod. Language A. 162 (1988).

10. June K. Inuzuka, Women of Color and Public Policy: A Case Study of the Women's Business Ownership Act, 43 STAN. L. REV. 1215 (1993).

11. Pub. L. No. 100-533, 102 Stat. 2689 (1988).

12. The group "women of color" itself represents a coalition across lines of ethnicity, class, and sexual orientation. This grouping is neither necessary nor inevitable as a matter of formal logic. It is, however, a powerful grouping politically, and one with a historical basis in the conditions of race and gender oppression in this society.

13. Similarly, "white" is a category derived from both the ideology of white supremacy and from opposition to it. The concept of whiteness, of course, is itself subject to deconstruction. See Neil Gotanda, A Critique of "Our Constitution is Color-Blind, 44 STAN. L. REv. 1 (1991).

Bernice Johnson Reagon describes the expanding identities of whites who participated in the Civil Rights Movement:

They were people who came South to work in the movement who were not Black. Most of them were white when they came. Before it was over, that category broke up-you know, some of them were Jewish, not simply white, and some others even changed their names. Say if it was Mary when they came South, by the time they were finished it was Maria, right? At some point, you cannot be fighting oppression and be oppressed yourself and not feel it.

Reagon, supra note 1 , at 363.

14. See, e.g., ElizabeTh V. Spellman, Inessential Woman: Problems of Exclusion in Feminist Thought (1988). 
ences and who chooses, nonetheless, to work with groups formed around the category of "women."

\section{The Multi-Cultural Feminist}

Sharon Parker begins her essay by telling of her genealogy, and in doing so echoes a practice familiar in native cultures. ${ }^{15}$ Like legal theorist Patricia Williams, who lets her readers know that she writes as an African-American woman whose genealogy includes slavery and rape, ${ }^{16}$ Parker introduces her work and herself through the prism of her lineal past. Bringing one's genealogy to one's work is more than a demonstration of respect for one's ancestors. It is a claim that theory reflects social position and experience, and it is a critique of theory that fails to disclose the particularities of its origin.

Unlike June Inuzuka, who operates in the world of practical politics, Sharon Parker chooses to complexify the notion of "women of color." She identifies herself as a "multi-ethnic" woman and includes "white" as one of the racial identities she claims. For Parker and the growing number of multi-ethnic feminists like her, the question of separate versus collective identity is both personal and political, implicating culture as much as coalition.

What does it mean to claim white, African, and Native ancestry? Physiognomy is not enough to lay claim to an ethnicity. Without the knowledge that comes from the living of Native American culture, a drop of Native American blood is meaningless. ${ }^{17}$ Implicit in Parker's statement of her ancestry is her commitment to the cultures represented by that ancestry, as well as her refusal to fit neatly into a single racial category.

Parker focuses explicitly on "herstory" and spirituality in her essay. More than Trask or Inuzuka, Parker speaks in the broad and visionary terms of cultural feminism and eco-feminism, branches of the feminist tradition that seek a women-centered spirit. Feminist spirituality is not often found in the pages of a law review, and Parker's writing will seem unfamiliar to some readers. We might ask why certain strands of feminism are more palatable to legal audiences. Are they better, more progressive, more theoretically sophisticated, or is it simply that they more closely resemble the discourses of power in the legal academy?

These three writers-Parker, Inuzuka, and Trask-have found work in coalition painful. Each describes the racism and condescension they have experienced. Each recounts the frustration that comes from trying to explain the most important aspects of one's life and creed to listeners who are ill-prepared to understand. Each suggests that coalition has limits of both tolerance and utility.

Why, then, given the frustration of coalition, do these women not retreat

15. Sharon Parker, Understanding Coalition, 43 StaN. L. Rev. 1193 (1993)

16. See generally Patricia J. Williams, The Alchemy of Race and Rights (1991).

17. Unless, of course, there is a degraded meaning attached to that drop of blood by the dominant culture. See Gotanda, supra note 13. 
into racial separatism? In the quest for a theoretical underpinning for social change movements, women of color have the choice of remaining in coalition or dispersing to do separate work. The emergence of feminist jurisprudence, critical race theory, critical legal studies, and the women of color and the law movement has raised fears of division and parochial separatism in the legal community. If it is so hard to work together, if the gulfs in experience are so wide, if the false universals of the modern age are truly bankrupt, what need binds us? What justifies unity in our quest for selfknowledge?

$\mathrm{My}$ answer is that we cannot, at this point in history, engage fruitfully in jurisprudence without engaging in coalition, without coming out of separate places to meet one another across all the positions of privilege and subordination that we hold in relation to one another.

\section{Theory OUt OF COAlition}

Through our sometimes painful work in coalition we are beginning to form a theory of subordination; a theory that describes it, explains it, and gives us the tools to end it. As lawyers working in coalition, we are developing a theory of law taking sides, rather than law as value-neutral. We imagine law to uplift and protect the sixteen-year-old single mother on crack rather than law to criminalize her. ${ }^{18}$ We imagine law to celebrate and protect women's bodies; law to sanctify love between human beings-whether women to women, men to men, or women to men, as lovers may choose to love; law to respect the bones of our ancestors; law to feed the children; law to shut down the sweatshops; law to save the planet.

This is the revolutionary theory of law that we are developing in coalition, and I submit that it is both a theory of law we can only develop in coalition, and that it is the only theory of law we can develop in coalition.

\section{A. Looking at Subordination From Inside Coalition}

When we work in coalition, as the writers in this symposium demonstrate, we compare our struggles and challenge one another's assumptions. We learn of the gaps and absences in our knowledge. We learn a few tentative, starting truths, the building blocks of a theory of subordination.

We learn that while all forms of oppression are not the same, ${ }^{19}$ certain predictable patterns emerge:

- All forms of oppression involve taking a trait, $\mathrm{X}$, which often carries with it a cultural meaning, ${ }^{20}$ and using $X$ to make some group the "other" and to reduce their entitlements and power.

18. See Dorothy Roberts, Punishing Drug Addicts Who Have Babies: Women of Color, Equality, and the Right of Privacy, 104 HARv. L. REv. 1419 (1991).

19. Trina Grillo \& Stephanie Wildman, Obscuring the Importance of Race: The Implications of Making Comparisons Between Racism and Sexism (or Other-Isms), 1991 DukE L.J. 397.

20. See Charles R. Lawrence III, The Id, the Ego, and Equal Protection: Reckoning With Unconscious Racism, 39 STAN. L. REV. 317 (1987). 
- All forms of oppression benefit someone, and sometimes both sides of a relationship of domination will have some stake in its maintenance. ${ }^{21}$

- All forms of oppression have both material and ideological dimensions. The articles on health, socioeconomics, and violence in this symposium show how subordination leaves scars on the body. ${ }^{22}$ The damage is real. It is material. These articles also speak of ideology. Language, including the language of science, law, rights, necessity, free markets, neutrality, and objectivity can make subordination seem natural and inevitable, justifying material deprivation.

- All forms of oppression implicate a psychology of subordination that involves elements of sexual fear, need to control, hatred of self and hatred of others.

As we look at these patterns of oppression, we may come to learn, finally and most importantly, that all forms of subordination are interlocking and mutually reinforcing.

\section{B. Ask the Other Question: The Interconnection of All Forms of Subordination}

The way I try to understand the interconnection of all forms of subordination is through a method I call "ask the other question." When I see something that looks racist, I ask, "Where is the patriarchy in this?" When I see something that looks sexist, I ask, "Where is the heterosexism in this?" When I see something that looks homophobic, I ask, "Where are the class interests in this?" Working in coalition forces us to look for both the obvious and non-obvious relationships of domination, helping us to realize that no form of subordination ever stands alone. ${ }^{23}$

If this is true, we've asked each other, then isn't it also true that dismantling any one form of subordination is impossible without dismantling every other? And more and more, particularly in the women of color movement, the answer is that "no person is free until the last and the least of us is free."

In trying to explain this to my own community, I sometimes try to shake people up by suggesting that patriarchy killed Vincent Chin. ${ }^{24}$ Most people

21. For an analysis of Hegel's discussion of the Master and Slave relationship, see Kendall Thomas, A House Divided Against Itself: A Comment on "Mastery, Slavery, and Emancipation," 10 CARDOzo L. REv. 1481 (1989); for consideration of the false consciousness that may keep people in situations that harm them, see Mari J. Matsuda, Pragmatism Modified and the False Consciousness Problem, 63 S. CAL. L. Rev. 1763 (1990).

22. See G. Chezia Carraway, Violence Against Women of Color, 43 STAN. L. REv. 1301 (1993); Kimberlé Crenshaw, Mapping the Margins: Intersectionality, Identity Politics, and Violence Against Women, 43 Stan. L. REv. 1241 (1993); Nilda Rimonte, $A$ Question of Culture: Cultural Approval of Violence Against Women in the Pacific-Asian Community and the Cultural Defense, 43 STAN. L. REv. 1311 (1993).

23. For an analysis of the relationship between sexism and heterosexism, see SUZANNE Pharr, Homorhobia: A WeAPON OF Sexism (1988).

24. Vincent Chin, a Chinese American, was murdered in Detroit by assailants who shouted racial slurs while attacking Chin with a baseball bat. See Detroit's Asian Americans Outraged by Lenient Sentencing of Chinese American Man's Killer, Rafu Shimpo, May 5, 1983 (on file with the Stanford Law Review). For other accounts of anti-Asian violence, see, for example, William Wong, Anti-Asian Violence, Forum, June 1989 (reflections on the Stockton, California massacre of Asian- 
think racism killed Vincent Chin. When white men with baseball bats, hurling racist hate speech, beat a man to death, it is obvious that racism is a cause. It is only slightly less obvious, however, when you walk down the aisles of Toys $\mathbf{R}$ Us, that little boys grow up in this culture with toys that teach dominance and aggression, while little girls grow up with toys that teach about being pretty, baking, and changing a diaper. And the little boy who is interested in learning how to nurture and play house is called a "sissy." When he is a little older he is called a " $\mathrm{f}-\mathrm{g}$." He learns that acceptance for men in this society is premised on rejecting the girl culture and taking on the boy culture, and I believe that this, as much as racism, killed Vincent Chin. I have come to see that homophobia is the disciplinary system that teaches men that they had better talk like 2 Live Crew or someone will think they "aren't real men," and I believe that this homophobia is a cause of rape and violence against women. I have come to see how that same homophobia makes women afraid to choose women, sending them instead into the arms of men who beat them. I have come to see how class oppression creates the same effect, cutting off the chance of economic independence that could free women from dependency upon abusive men.

I have come to see all of this from working in coalition: from my lesbian colleagues who have pointed out homophobia in places where I failed to see it; from my Native American colleagues who have said, "But remember that we were here first," when I have worked for the rights of immigrant women; from men of color who have risked my wrath to say, "But racism is what is killing us. Why can't I put that first on my agenda?"

The women of color movement has, of necessity, been a movement about intersecting structures of subordination. This movement suggests that antipatriarchal struggle is linked to struggle against all forms of subordination. It has challenged communities of color to move beyond race alone in the quest for social justice.

\section{Beyond Race Alone}

In coalition, we are able to develop an understanding of that which Professor Kimberlé Crenshaw has called "inter-sectionality."25 The women of color movement has demanded that the civil rights struggle encompass more than anti-racism. There are several reasons for this demand. First, and most obviously, in unity there is strength. No subordinated group is strong enough to fight the power alone, thus coalitions are formed out of necessity. ${ }^{26}$

American school children and the Vincent Chin case); L.A. Group Says Skinheads Tied to Anti-Asian Violence, Asian Week, Feb. 23, 1990, at 3; Arnold T. Hiura, The Unfortunate Case of Jim Loo. The Hawaii Herald, July 6, 1990, at A-13, col. 1 (racially motivated murder of Chinese-American man in Raleigh, North Carolina); Asian Pacific American Coalition USA, Report: Stockton Killings Racially Motivated, APAC Alert, Oct. 1989, at 1.

25. See Kimberlé Crenshaw, Demarginalizing the Intersection of Race and Sex: A Black Feminist Critique of Antidiscrimination Doctrine, Feminist and Antiracist Politics, 1989 U. CHI. LEGAL F. $139,140$.

26. In addition to the political power that comes from unity, there is also a joy and empower- 
Second, some of us have overlapping identities. Separating out and ranking oppression denies and excludes these identities and ignores the valid concerns of many in our constituency. To say that the anti-racist struggle precedes all other struggles denigrates the existence of the multiply oppressed: women of color, gays and lesbians of color, poor people of color, most people of color experience subordination on more than one dimension.

Finally, perhaps the most progressive reason for moving beyond race alone is that racism is best understood and fought with knowledge gained from the broader anti-subordination struggle. Even if one wanted to live as the old prototype "race man," it is simply not possible to struggle against racism alone and ever hope to end racism.

These are threatening suggestions for many of us who have worked primarily in organizations forged in the struggle for racial justice. Our political strength and our cultural self-worth is often grounded in racial pride. Our multi-racial coalitions have, in the past, succeeded because of a unifying commitment to end racist attacks on people of color. Moving beyond race to include discussion of other forms of subordination risks breaking coalition. Because I believe that the most progressive elements of any liberation movement are those who see the intersections (and the most regressive are those who insist on only one axis), I am willing to risk breaking coalition by pushing intersectional analysis.

An additional and more serious risk is that intersectional analysis done from on high, that is, from outside rather than inside a structure of subordination, risks misunderstanding the particularity of that structure. Feminists have spent years talking about, experiencing, and building theory around gender. Native Americans have spent years developing an understanding of colonialism and its effect on culture. That kind of situated, ground-up knowledge is irreplaceable. A casual effort to say, "Okay, I'll add gender to my analysis," without immersion in feminist practice, is likely to miss something. Adding on gender must involve active feminists, just as adding on considerations of indigenous peoples must include activists from native communities. Coalition is the way to achieve this inclusion.

It is no accident that women of color, grounded as they are in both feminist and anti-racist struggle, are doing the most exciting theoretical work on race-gender intersections. It is no accident that gay and lesbian scholars are advancing social construction theory and the analysis of sexuality in subordination. In raising this I do not mean that we cannot speak of subordination second-hand. Rather, I wish to encourage us to do this, and to suggest that we can do this most intelligently in coalition, listening with special care to those who are actively involved in knowing and ending the systems of domination that touch their lives.

ment that comes from finding connections to others. As a student participant in the Women of Color Conference said: "The energy that comes from comparing experiences; the nods of 'uh-huh' when one person's story of oppression at one axis triggers another person to remember subordination at a different axis; the making of new friends; the renewal of old friendships; the knowledge that we are not alone in our struggles-all are benefits of coalition work." 


\section{CONCLUSION}

This essay has suggested a theory of subordination that comes out of work in coalition. The Third National Conference on Women of Color and the Law was a place for this work. The women and men of many races who worked on the conference can tell us that making this place is not easy. The false efficiencies of law schools, where we edit facts out of cases and cabin concepts such as "crime" and "property" into semester-sized courses, illprepare us for the long, slow, open-ended efficiencies of coalition. Planning the conference involved more than inviting speakers and sending out registration forms. It took a literal thousand human hours spent talking long into the night, telling stories of self and culture and history, before the Stanford Women of Color and the Law Conference could happen. To lay the foundation of trust upon which people could teach, challenge, listen, learn, and form theory out of coalition took time and patience. As often happens in the slow-cooking school of theory-building, the organizers wondered whether all that talk was getting anywhere. Cutting off discussion and avoiding conflict would have saved hours early on, but coalition at its best never works that way. The slow and difficult early work gives us efficiencies when we need them: when the real challenges come, when justice requires action, when there is no time to argue over how to proceed. The organizers of the conference, like the women writing on coalition for this volume, have forged bonds and created theory that will sustain them in the contentious closing days of this century. When called upon they will answer with a courage and wisdom born in their place of coalition. 